\title{
A 99-YEAR CHRONOLOGY OF BLUE PINE (PINUS WALLICHIANA) TREE-RINGS CONCERNING INTERANNUAL CLIMATE VARIABILITY IN THE CENTRAL HIMALAYAS OF NEPAL
}

\author{
GAUTAM, D. ${ }^{1,2}-$ Shrestha, N. M. ${ }^{2}$ - GAIRE, N. P. ${ }^{3,7}-$ Roth, B. E. ${ }^{4}$ - JANDUG, C. M. B. ${ }^{5,6}$ \\ TONG, X. J. ${ }^{1 *}-$ LIU, Q. J. ${ }^{* *}$ \\ ${ }^{1}$ School of Ecology and Nature Conservation, Beijing Forestry University, Beijing 100083, \\ China (e-mail: deepakgautamiof@gamil.com) \\ ${ }^{2}$ Institutes of Forestry, Tribhuvan University, Pokhara, Nepal
}

${ }^{3}$ Key Laboratory of Tropical Forest Ecology, Xishuangbanna Tropical Botanical Garden, Chinese Academy of Sciences, Menglum, Mengla, Yunnan 666303, China

${ }^{4}$ Associate Director, Seed Tree, Stockton Springs, Maine 04981, USA

${ }^{5}$ School of Forestry, Beijing Forestry University, Beijing 100083, China

${ }^{6}$ College of Forestry and Environmental Science, Caraga State University, Philippines

${ }^{7}$ Patan Multiple Campus, Tribhuvan University, Lalitpur, Nepal

*Corresponding authors

e-mail: tongxj@bjfu.edu.cn; liuqijing@bjfu.edu.cn

(Received 14 $4^{\text {th }}$ May 2020; accepted 29 Jul 2020)

\begin{abstract}
We conducted a dendroclimatic study in the Mustang region of the Himalayas in Nepal with aims to develop the tree-ring chronology and to check response of blue pine (Pinus wallichiana) radial growth with climate variation in the area. We extracted 120 tree cores at an altitudinal range of 2350 to $2550 \mathrm{~m}$ and develop a 99-year long tree-ring width chronology of blue pine which spans from 1913 to 2011.Precipitation and temperature were the main climatic factors limiting the radial growth of $P$. wallichiana. Winter and spring time precipitation was positively correlated to blue pine growth, specifically: precipitation during the previous November $(r=0.43, p<0.01)$, December $(r=0.39, p<0.05)$ and current March $(r=0.34, p<$ $0.05)$. Similarly, there was a positive correlation between growth and September temperature of the current year $(r=0.398, p<0.05)$, while correlation with temperature in previous year October $(r=-0.446, p<0.05)$ and December $(r=-0.424, p<0.05)$ was negative. Site conditions played a significant role in modulating the effect of precipitation and temperature on radial growth. Longer term regional scale dendrochronological studies are needed to improve our understanding on long-term climate change and its impact on forest growth.
\end{abstract}

Keywords: climate change, climatic variations, dendrochronology, Mustang, moisture stress

\section{Introduction}

The Himalaya Mountain region consists of a broad bioclimatic zone (Rai et al., 2019) and is experiencing a rate of warming several times greater than the global average (Shrestha and Aryal, 2011). Small changes in the mean or variability of climatic variables may result in several magnitudes the change in the frequency and intensity of extreme weather events, thereby creating challenging conditions for living organisms to adapt (Stocker et al., 2013). These extreme weather events are expected to alter current and future ecosystem dynamics leading to shifts in species distribution, population structures, vegetation composition, phenology, and length of growing 
seasons (Ziaco et al., 2014; Gaire et al., 2017a). The Himalayan region of Nepal is highly sensitive to the effects of a changing climate. The mean air temperature in Nepal has been increasing at a rate of 0.04 to $0.06{ }^{\circ} \mathrm{C} /$ year, which is faster than the global average (Shrestha and Aryal, 2011). Nepal is at a disadvantage in understanding the effects of a changing climate due to limited instrumental weather data (Bräuning, 2004); however, alternative tools such as tree-rings, pollens, lake sediments and ice-cores may be helpful for the reconstruction of past climate (Cook and Kairiukstis, 1990; Gaire et al., 2019). Dendrochronology and its sub-disciplines, such as dendroclimatology, use tree rings to reconstruct yearly variations in climate occurring prior to the interval covered by direct weather measurements (Fritts, 1976; Speer, 2010). Dendrochronology can date the formation of tree rings to an exact calendar year (Speer, 2010). In the last decade, several studies related to tree radial growth response to climate in the Himalaya in Nepal have been conducted (Dawadi et al., 2013; Liang et al., 2014; Gaire et al., 2017; Sigdel et al., 2018). Past studies related radial growth to precipitation (Kharal et al., 2014; Liang et al., 2014; Panthi et al., 2017; Gautam et al., 2021; Aryal et al., 2020), temperature (Gaire et al., 2014; Kharal et al., 2017; Aryal et al., 2018) and a combination of temperature and precipitation (Sano et al., 2005; Sohar et al., 2017).

Conifers are the major species studied under dendrochronological research due to their clearly visible annual ring structure (Gaire et al., 2013; Thapa et al., 2017; Bhandari et al., 2019). More than 60 scientific studies have been carried out in Nepal Himalayas using tree-ring data (Gaire et al., 2013). In Nepal, the longest chronology of a conifer species was for Tsuga dumosa, which is 1141 years long ranging from 856 to 1996 (Cook et al., 2003). Blue pine (Pinus wallichiana A. B. Jackson), an evergreen tree native to the Himalayan Mountain region, is widely used in multiaspects dendrochronological research (Jackson, 1994; Gaire et al., 2013, 2019; Shah et al., 2019; Gautam et al., 2020). Schmidt et al. (1999) developed a first master tree-ring chronology for Nepal covering a time span ranging from 1324 to 1997 which included $P$. wallichiana from different regions of western and eastern Nepal. Subsequently, Cook et al. (2003) developed the longest chronology to date of $P$. wallichiana, 694 years ranging from 1303 to 1996, from archeological wood collected from historical structures in Bhratang, Nepal. Similarly, Shah et al. (2019) developed a 175-year long chronology of $P$. wallichiana, ranging in origin from 1840 to 2014, from Kasmir, western Himalaya, India. Yadav and Bhattachryya (1996) used $P$. wallichiana chronology for the study of glacial behavior in the western Himalaya. They concluded that this tree growing in subalpine Himalayan regions would be an excellent candidate to understand past glacier behavior in the region. Recently, Gaire et al. (2019) developed a 405-year long tree-ring chronology of $P$. wallichiana extending from 1611 to 2015 from Dolpo region in western Nepal and reconstructed spring-summer season drought. Similarly, 527 years and 495-years tree-ring chronologies have been developed using $P$. wallichiana from the Bagrot and Astor regions of Karakorum Mountains in northern Pakistan (Asad et al., 2017). For Abies spectabilis, Udas (2009) developed chronologies of 107 and 149 years from the two sites in the Mustang district consisting of 46 series from 26 trees. However, there is no study in the Mustang region in the Himalayas focusing only in the Blue pine growth from the natural forest stand. Therefore, to extend the knowledge of tree radial growth as related to past climate in the Himalayas, a study of blue pine (P. wallichiana) was conducted in the Mustang district of Nepal.

\section{Materials and Methods}

\section{Study area}

The study was carried out in Kunjo area of Mustang district (Figure 1). Mustang (Latitude: $28.59^{\circ} \mathrm{N}$; Longitude: $83.50^{\circ} \mathrm{E}$ ) is situated between the Annapurna and Dhaulagiri Himalaya ranges. The distribution of $P$. wallichiana in the Mustang district is noted for its presence at higher elevations which makes it highly suitable for establishing climate-tree growth relationships (Schweingruber et al., 1992). This district is characterized by a predominant rain shadow effect where annual rainfall is less than $200 \mathrm{~mm} / \mathrm{yr}$ with temperatures ranging from $-20{ }^{\circ} \mathrm{C}$ in the winter 
to $26{ }^{\circ} \mathrm{C}$ in the summer (NTNC, 2008). The analysis of weather data from the Jomsom station (1985 to 2016) indicates an overall increasing trend of maximum, minimum and mean annual temperatures by $0.0369^{\circ} \mathrm{C}$ year ${ }^{-1}, 0.0067^{\circ} \mathrm{C}_{\text {year }}{ }^{-1}$ and $0.0217^{\circ} \mathrm{C}$ year ${ }^{-1}$, respectively (Adhikari, 2018). Similarly, annual precipitation has also trended upwards at a rate of $3.1823 \mathrm{~mm}$ year $^{-1}$. The year with the highest rainfall $(432.1 \mathrm{~mm})$ was recorded in 1995 and the lowest $(116.1 \mathrm{~mm})$ was in 1988 (Adhikari, 2018). The $P$. wallichiana forest is located in the southern part of the Mustang district and the associated weather station at Kunjo is in the Thasang Rural Municipality which lies at 2350 to $2550 \mathrm{~m}$ in elevation with an annual rainfall of $1200 \mathrm{~mm}$. Trees at the upper boundary of the species distribution are more sensitive to climate variations than trees at lower elevations (Kharal et al., 2014). Therefore, in this study, we collected samples from the upper elevation limit of the forest. The study area is dominated by temperate coniferous and mixedspecies forests of $P$. wallichiana, Juniperus recurva, Abies spectabilis, Tsuga dumosa and Rhododendron arboreum as the dominant tree species, and Cupressus torulosa, Ilex dipyrena, Taxus wallichiana, Betula alnoides and Acer spp. less dominant (Christensen et al., 2009). Geologically, granite and gneiss are the main rock types in the study area which form very coarse textured, acidic and shallow soils. The study sites consist of $P$. wallichiana in pure stands or mixed with other conifers and broadleaves.

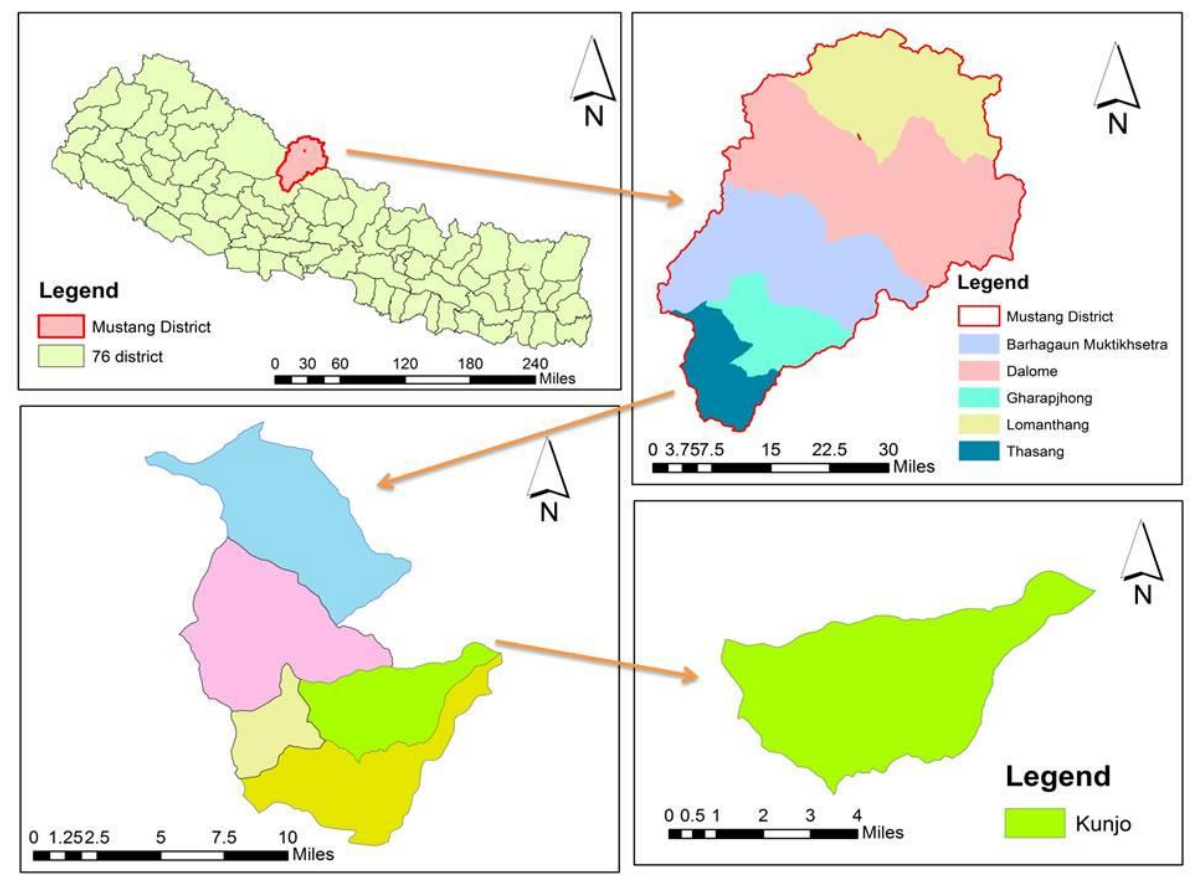

Figure 1. Map showing the locations of sampling site (Kunjo)

\section{Study species}

Blue pine is a large evergreen tree native to the Himalayan Mountain region, widely distributed at elevations ranging from 1,800 to 3,600 m and occasionally over 4,000 $\mathrm{m}$ (Jackson, 1994; Gaire et al., 2019). This species is often found in mixtures with $P$. roxburghii on southern aspects at lower elevations (Jackson, 1994). It is a strongly light demanding, less fire resistant than $P$. roxburghii, and is widely distributed throughout the Himalayas of Nepal. This species is sensitive to climate variation and is therefore well suited to dendrochronology study. Compared to other conifer species in the Himalaya region of Nepal, P. wallichiana is relatively less studied (Gaire et al., 2013) 


\section{Field work}

Dominant and co-dominant $P$. wallichiana trees were sampled from rocky terrain on southern slopes at elevations ranging from 2350 to $2550 \mathrm{~m}$ (Table 1). Generally, two cores per tree were extracted at breast height $(1.3 \mathrm{~m})$ on opposite sides of the bole (Gaire et al., 2020), parallel to the contour slope. In total, 120 cores from 60 individual trees were collected using a Swedish increment borer following standard techniques (Speer, 2010). The extracted cores were immediately transferred to plastic straw pipes and brought to Dendro-lab for analysis.

Table 1. Location of meteorological stations and sampling site in Mustang district

\begin{tabular}{c|c|c|c}
\hline Meteorological stations & Altitude (m) & Latitude & Longitude \\
\hline Lete & 2384 & $28.38^{\circ} \mathrm{N}$ & $83.36^{\circ} \mathrm{E}$ \\
Marpha & 2566 & $28.45^{\circ} \mathrm{N}$ & $83.42^{\circ} \mathrm{E}$ \\
Jomsom & 2744 & $28.47^{\circ} \mathrm{N}$ & $83.43^{\circ} \mathrm{E}$ \\
\hline
\end{tabular}

\begin{tabular}{c|c|c|c}
\hline Sampling site (name) & Altitude range (m) & Latitude & Longitude \\
\hline Kunjo & $2350-2550$ & $28.64^{\circ} \mathrm{N}$ & $83.66^{\circ} \mathrm{E}$ \\
\hline
\end{tabular}

\section{Laboratory work}

Core samples were analyzed using established dendrochronological procedures (Speer, 2010). Surfaces of the cores were successively smoothed by hand with a series of sanding papers progressing to finer grits (Gaire et al., 2020). Prior to chronology development, all tree rings in each core samples were counted using a stereo-zoom microscope and dated to the calendar year. Very young series (individual series with less than 50 rings) were discarded from further analysis. Tree-ring widths were measured to the nearest $0.01 \mathrm{~mm}$ using the LINTAB measuring system connected to a computer with TSAP-Win associated software (Rinn, 2003). Cross-dating of chronologies corrected errors from false and missing rings or measurement errors to ensure accurate dating of the annual increments. This was done using a visual verification procedure in the TSAP-Win software and further validated through the computer program COFECHA (Holmes, 1983; Grissino-Mayer, 2001). Measured tree-ring series with potential errors identified through COFECHA were double checked prior to removal from further analysis. Finally, a total of 27 series were chosen for chronology development and further analysis, after discarding the very young series and problematic series including those broken or with abnormal growth properties. The software package, ARSTAN, was used to standardize all the tree-ring series (Cook and Holmes, 1986). The purpose of standardization was to: a) remove non-climatic age-related trends from the ring-width series, and $b$ ) allow the resulting standardized values to be averaged into a mean value function by adjusting the series for varying growth rates due to differing tree ages and rates of growth. Conventional negative exponential curvilinear or linear regression (any slope) analysis was used to detrend the tree-ring series. This procedure removed age effects due to biological growth trends and other low frequency variations due to stand dynamic features. Then, all detrended series were averaged to chronologies by computing the mean value function. The mean value function concentrates on climate related environment signals and averages out noise from endogenous or exogenous disturbances (Fritts, 1976). For this analysis, a robust biweight mean estimation (Mosteller and Tukey, 1977) was used which removed random signals that were related to local disturbances. Finally, a set of three chronologies, were developed: (i) a standard chronology, reflecting variations after removing age effects; (ii) a residual chronology, containing only high-frequency variations after removing autocorrelation from the standard chronology; and (iii) an ARTSAN chronology composed of the residual chronology reincorporated with the pooled auto regression. Chronology statistics such as mean tree-ring width or mean index, standard deviation, standard error, mean sensitivity and autocorrelation were 
calculated. Chronology confidence was estimated by calculating the running Expressed Population Signal (EPS) using a 30-year window with an overlap of 29 years. Wigley et al. (1984) has suggested an EPS value of 0.85 as an acceptable value demonstrating a strong common signal present in a chronology (Cook and Kairiukstis, 1990).

\section{Meteorological data}

The climate data at the nearest meteorological stations in Kunjo (Lete 2,384 m, Marpha 2,566 $\mathrm{m}$ and Jomsom 2,744 m) were obtained from the Department of Hydrology and Meteorology (Table 1). The precipitation data from Lete and Jomsom stations covered the measurement period from 1987 to 2010 and 1969 to 2007, respectively. The temperature data ranges from 1998 to 2007 in Lete and 1961 to 2010 in Jomsom, however, in Jomsom there was 10 years of missing data. Missing temperature and precipitation data from these stations was predicted by using fitting trend line. In order to estimate past climate data, the CRU grid data was used by covering Lete and Jomsom meteorological stations (http://www.cgiar-csi.org/data/climate/item/52-cru-ts-21climate-database) and sampling site. The climograph of precipitation and temperature of Lete and Jomsom is presented in Figure 2.

\section{Climate and tree-ring growth relationships}

Both temperature and precipitation were highly correlated among the three meteorological stations of the Mustang district (Kharal et al., 2014). Pearson correlation analysis was used to examine how the climatic variables of monthly mean temperature and total precipitation, influence tree-ring radial growth (Fritts et al., 1971). A climatic window of 16 months starting from the previous year September until the December of the current year was used by following previous tree-ring based studies from the Nepal Himalayas (Sano et al., 2005; Kharal et al., 2017; Gaire et al., 2019). This period of year was selected since climate conditions during the previous and current years can affect the amount of carbon fixed and allocated to tree growth (GrissinoMayer and Butler, 1993).

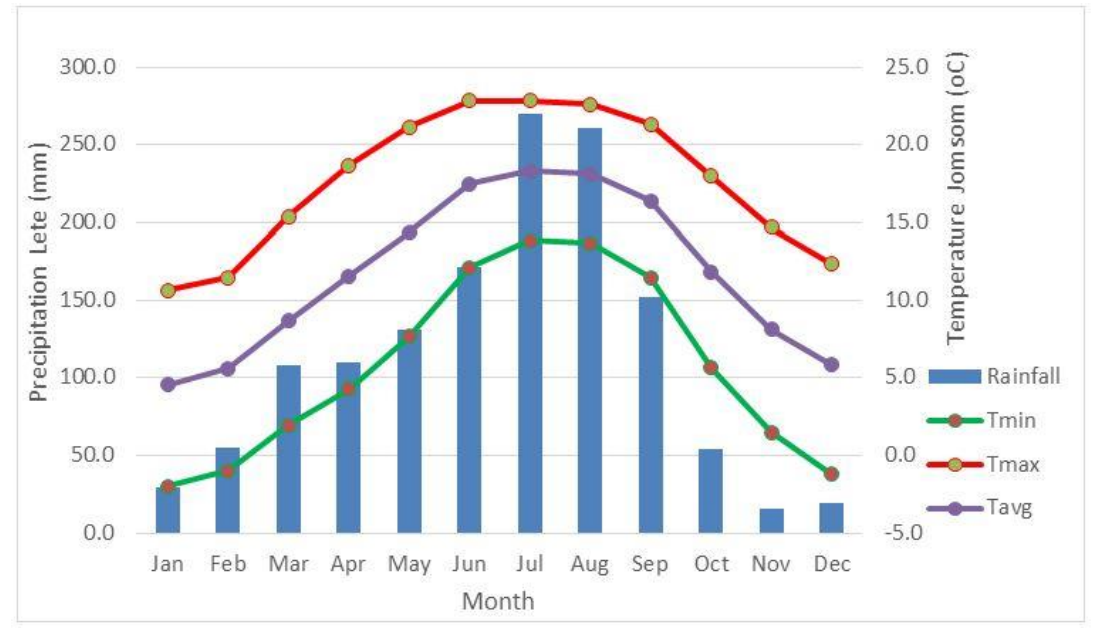

Figure 2. Average monthly precipitation of Lete and temperature of Jomsom stations

\section{Results}

\section{Chronology statistics}

From the 27 well-dated series, a 99-year chronology of $P$. wallichiana spanning from 1913 to 2011 was developed (Figure 3). There was a progressive decrease in growth from 1913 to 1925, followed by a four-year increase to 1929 and then again, another cycle to 1943. Comparing this 
growth pattern with the CRU precipitation data during the period of increased growth, August rainfall was found to be higher than in other years. From 1943 onwards, radial tree-ring growth fluctuated at constant rate, with a distinct increase over the period of 1995 to 1998, during which, August rainfall was also found to be above average. This pattern was also seen at the Lete station's rainfall data. Increased radial growth was associated with surplus (above average) rainfall in current year March, and previous year November and December. There are distinct periods of decreased August rainfall in 1925, 1932-1939, 1972, 1985 and 1999 which were associated with reduced radial growth (Graph not shown). While doing comparison with monthly average temperature, a reduced temperature during October through December of the previous year was found to be improved the standard chronology (Graph not shown).

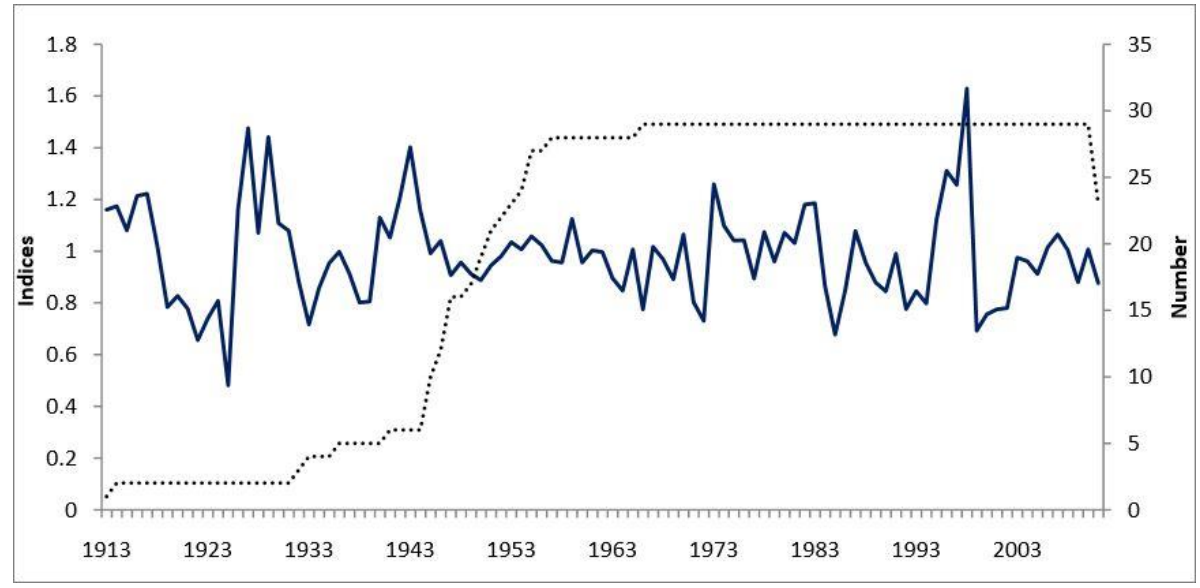

Figure 3. Tree ring width chronology of Pinus wallichiana. Solid line represents the ring width chronology and dash line represent the sample depth

The chronology statistics of both standard and residual chronologies were calculated. The correlation with the master series was 0.415 and the mean between trees correlation was calculated to be 0.211 with a standard deviation and error of 0.183 and 0.012 , respectively. The mean sensitivity of the standard chronology was found to be 0.145 and that of the residual chronology was 0.16 with a standard deviation of the standard chronology and residual chronology to be 0.183 and 0.164 , respectively. The autocorrelation value of standard chronology was 0.394 and that of residual chronology was 0.004. Expressed population signal (EPS) is a measure of verification of representation of the sample to the population with a minimum threshold of 0.85 . In this study, the EPS was found to be 0.846 at the $20^{\text {th }}$ sample, 0.852 at the $21^{\text {st }}$ sample, and 0.858 at the $22^{\text {nd }}$ sample. Mean annual growth rate was $3.51 \mathrm{~mm}$ with a variance of 0.27 . After checking the chronology statistics of standard and residual chronology, we selected the residual chronology for tree-ring and climate relation analysis.

\section{Comparison between $\mathrm{CRU}$ and station climate data}

Since precipitation data at Lete is limited to 1971 and forward, this is compared with CRU data through correlation analysis and is displayed in Figure 4. It was found that mean monthly precipitation correlation of January, March, October, November and December were highly significant whereas April and September were less significant. Similarly, mean monthly temperature correlations of January, February, March, June, July and November were highly significant whereas April was less significant. 


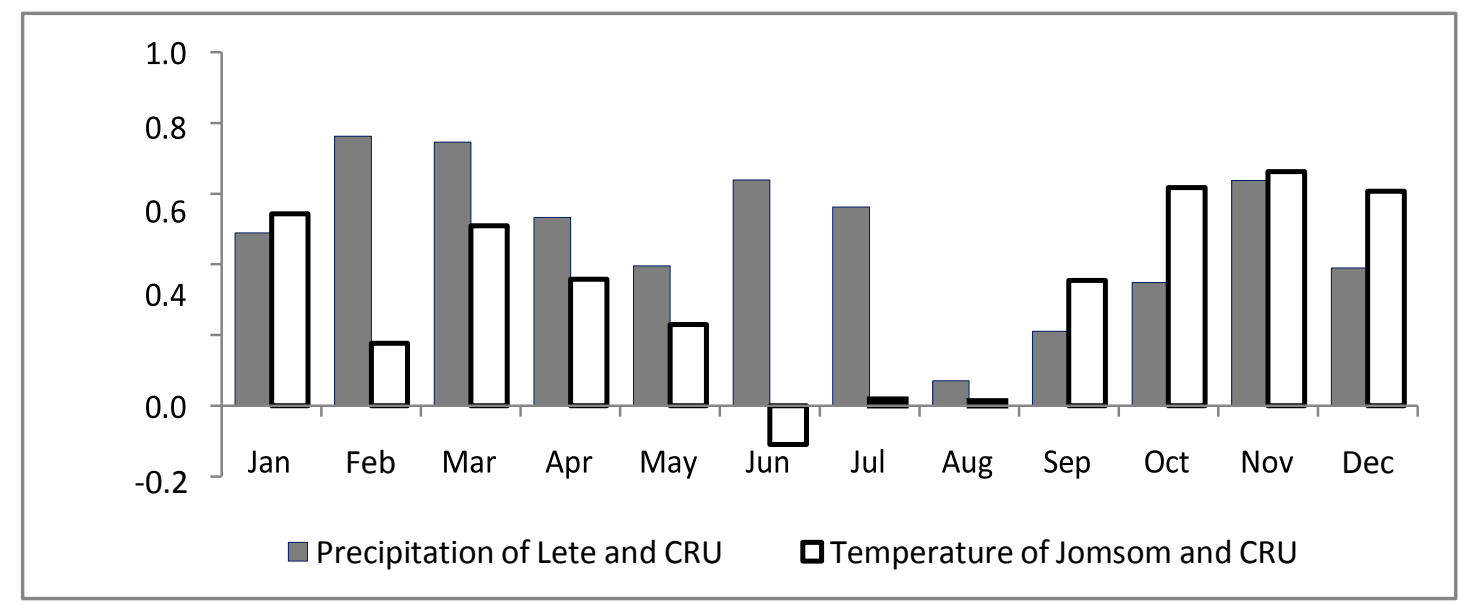

Figure 4. Correlation between CRU and meteorological station's mean monthly precipitation and temperature data

Due to a lack of temperature data from Lete prior to 1998, a comparison with Marpha and Jomsom stations was used to fill the data gap (Figure 5). Correlation of Lete station's mean monthly temperatures with Jomsom was highly significant for January and February, while less significant with March, April, September, October and November. Although, Marpha station is closer geographically to Lete station, correlation with Jomsom was higher than Marpha and was used to correlate temperature to tree-ring radial growth.

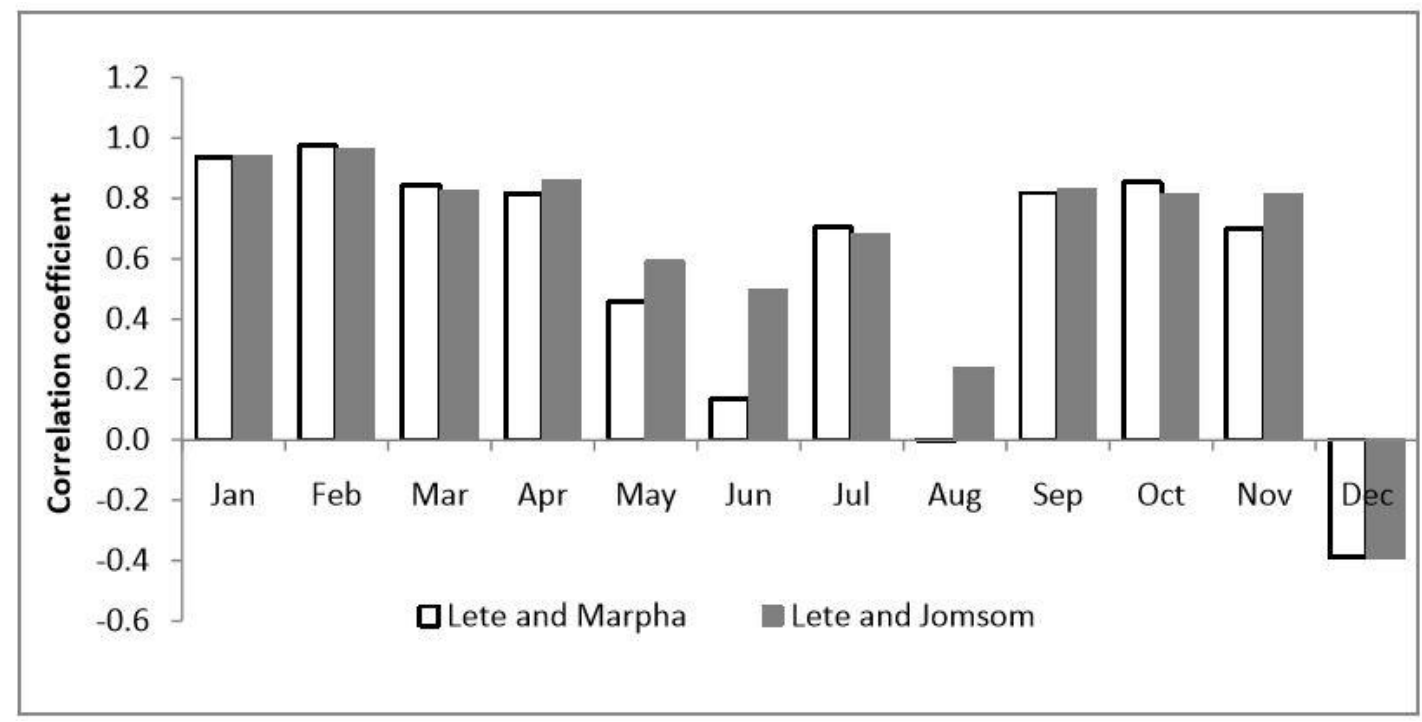

Figure 5. Mean monthly temperature correlation of Lete with Marpha and Jomsom

\section{Climate and tree growth relationship}

In this analysis, 16 climatic period variables were correlated with the residual tree-ring chronology from 1913 to 2011 (Figure 6). Figure 6 depicts the correlation of residual chronology with mean monthly precipitation and temperature. Tree-ring growth was positively correlated with current year March precipitation $(r=0.34, \mathrm{p}<0.05)$ and the previous year's November and December precipitation $(r=0.43, \mathrm{p}<0.01 ; \mathrm{r}=0.39, \mathrm{p}<0.05$, respectively) (Figure 6 ). We found a significant negative correlation between the tree growth and temperature at Jomsom station for 
previous year's October and December $(0.446, \mathrm{p}<0.05$ and $0.424, \mathrm{p}<0.05$, respectively), whereas, a significant positive relationship with current September temperature $(0.4, \mathrm{p}<0.05)$ (Figure 6).

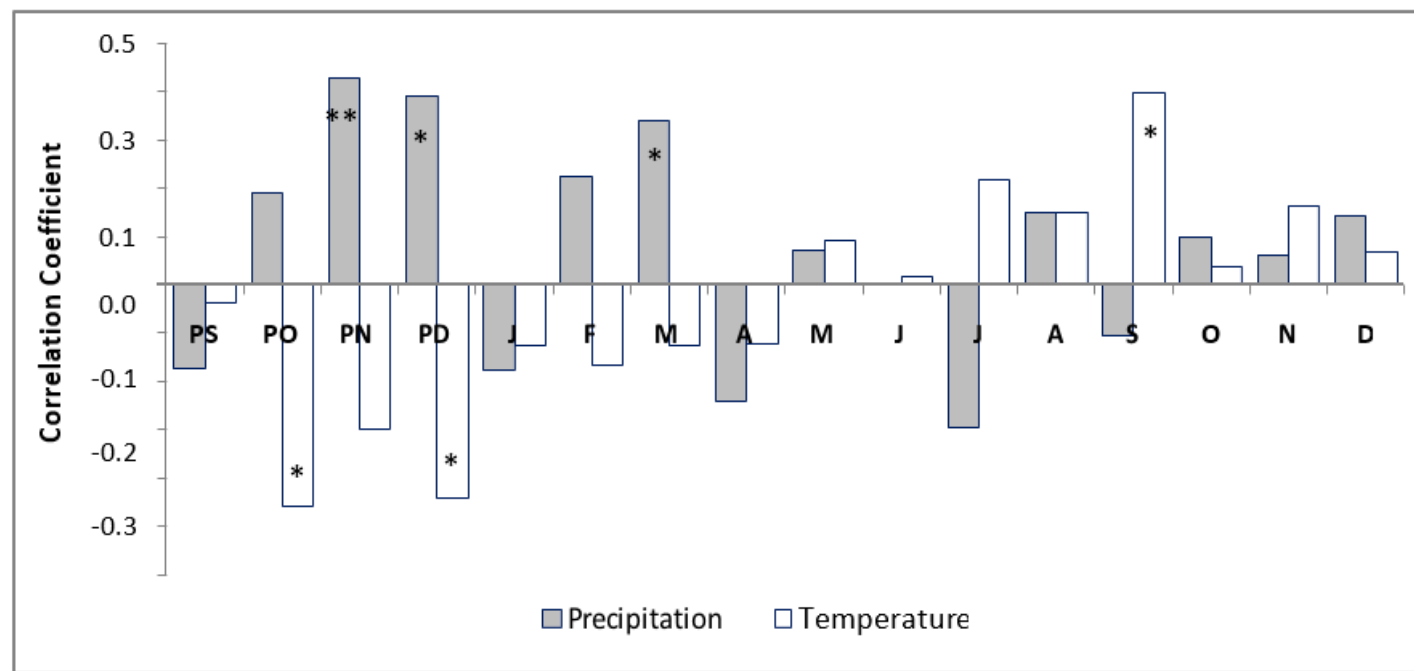

Figure 6. Correlation of standard chronology with monthly average precipitation and temperature. The PS to D stands for the name of the months starting from previous year September to current year December. Note: ** Significant at $p<0.01$, * Significant at $p<0.05, P$ : Previous, Month: Initials of each month (J: January, F: February...D: December)

\section{Discussion}

\section{Dendroclimatic potential of Pinus wallichiana from Mustang}

We developed a 99-year tree-ring width chronology of $P$. wallichiana dating back to 1913 with a mean sensitivity of 0.145 . The chronology statistics of the species depicted its dendroclimatic potential (Fritts, 1976; Speer, 2010). The present study revealed a relatively low chronology mean sensitivity despite being carried out on a harsh southern slope; this may be attributed to a well distributed rainfall with a dry period not exceeding two months (Fritts, 1976). The low mean sensitivity was unexpected, since most of the Mustang region is dry and in a rain shadow with precipitation concentrated to southern areas. However, the mean sensitivity we obtained for blue pine from Mustang region is comparable to that reported for the same species from the Dolpa in the central Himalaya in Nepal (Gaire et al., 2019) and chronology from the northwest Himalaya (Bhattacharyya et al., 1988). In order to get a clear signal of tree-ring radial growth as influenced by weather, areas with human and natural disturbance such as grazing, firewood collection, and selective logging should be avoided. Trees growing on dry sites usually demonstrate higher inter-annual growth variability than trees from temperature limited sites (Liang et al., 2008) which is typical for conifers growing in humid environments (Fan et al., 2009). In the subalpine temperate region, conifers demonstrate a low mean chronological sensitivity under mesic climate conditions when compared to arid sites (Bhattacharyya and Chaudhary, 2003). Most of our tree-ring series were relatively young (all less than 100 years old), that could be another reason for low mean sensitivity (Fritts, 1976).

In this study, we developed a 99-year long tree-ring chronology of $P$. wallichiana extending from 1913 to 2011. This chronology has low autocorrelation, moderate mean sensitivity and a high standard deviation which are considered suitable for dendroclimatic analysis (Fritts, 1976) and the EPS was greater than of 0.85, a commonly used threshold limit (Wigley et al., 1984). In the current study, the mean growth rate was $3.51 \mathrm{~mm}$ which is greater than the mean annual growth 
rate documented in the Dolpa region of Nepal (Gaire et al., 2019). The low autocorrelation (0.004) indicates that the previous year's growth effect on the current growth is minimal in residual chronology (Speer, 2010) and the EPS value of our chronology is greater than the threshold. These values are similar to those of $P$. wallichiana reported from the different regions in the Himalayas (Asad et al., 2017; Gaire et al., 2019; Shah et al., 2019). Asad et al. (2017) obtained similar chronological statistics from two different locations in western Himalaya in Pakistan, where SD $=0.17$ and $0.21, \mathrm{MS}=0.14$ and $0.13, \mathrm{EPS}=0.94$ and 0.90. Similarly, Gaire et al. (2019) carried out a similar investigation in the central Himalaya and documented similar chronology statistics: $\mathrm{MS}=0.156, \mathrm{SD}=0.229$, EPS (0.955) greater than the threshold with a high SNR (21.23), which indicate that the pine chronologies are suitable for dendroclimatic study.

\section{Climate change impact on Pinus wallichiana}

Over the past decade in the Himalayan region, several studies have investigated tree growth response to climate (Gaire et al., 2013, 2017, 2019, 2020; Dawadi et al., 2013; Ling et al., 2014; Kharal et al., 2017; Panthi et al., 2017; Sigdel et al., 2018). Based on published results, tree growth demonstrated a diverse response to climate variation in the Himalaya with some studies indicating that growth was primarily controlled by precipitation at higher elevations (Dawadi et al., 2013; Panthi et al., 2017; Gautam et al., 2021). Some studies showed that growth was primarily controlled by temperature variation (Gaire et al., 2014, 2020; Thapa et al., 2015; Kharal et al., 2017), while others concluded that both precipitation and temperature could significantly influence tree growth (Sohar et al., 2017). Overall, there is general agreement that seasonal climatic variation highly influences the growth of Himalayan conifers (Dawadi et al., 2013).

In order to understand the influence of seasonal variation in precipitation on blue pine tree growth, Shah et al. (2009) combined monthly climate data for pre-monsoon months, i.e. December through April. They reported that monsoon precipitation (July-August) did not play a significant role in limiting the tree growth in the studied eastern Himalaya region. Correlation analysis between monthly mean rainfall and radial growth of $P$. eliottii revealed a significant negative correlation with current year May precipitation and a significant positive correlation with current September precipitation (Harley et al., 2011). Pfeifer et al. (2005) found summer and the preceding autumn (September-October) as the dominant climatic factors controlling tree ringwidths of $P$. cembra in Western Austria.

We found that the growth of blue pine in the Mustang is primarily influenced by the winter and spring season climate and secondly by temperature during late summer. The present study revealed that current September temperature had positive control over the radial growth, whereas October and December temperatures in the previous year had a negative control over the radial growth. The month of September is physiologically active for growth as moisture is generally available owing to monsoon precipitation and groundwater, however low temperatures could limit respiration, photosynthesis, and other biochemical processes essential for growth (Fritts, 1976). Similarly, low temperature in September may cause early cessation of the growth. These environmental conditions are typical in the areas in this study at the upper elevation limit of this species. A high temperature in previous year October and December with a high wind can cause desiccation effect in the temperate and subalpine regions. On the other hand, a high temperature during early winter can promote for melting of snow leading to less snow accumulation to supply water for following growing season. These could be the possible reasons why we obtained positive relations with winter precipitation but negative with the temperature. Temperature effects are most apparent on south-facing and exposed slopes on shallow well drained soils or those with restricted root distributions (Fritts, 1976; Fan et al., 2009). Photosynthesis is sensitive to temperature (Fritts, 1976). Previous studies indicated that winter month temperatures in the previous year were found to have a positive relationship with the radial tree-ring growth of blue pine in Arunachal area in eastern India (November- December) (Shah et al., 2009) and (December-February) Gangotri region in western India Himalaya (Yadav and Bhattacharyya, 1996). This direct relationship between tree growth and winter temperature indicates that 
Himalayan pine trees carry on a significant amount of photosynthesis during warm winters, with stored energy reserves used in the following growing season (Singh and Yadav, 2000; Shah et al., 2019). Similar observations (October and December-January) have been noted in Himalayan pine trees growing at lower altitudes (Yadav and Amalava, 1997).

A tree-ring study was carried out by Udas (2009) in the Mustang district, close to our study area, by using Abies spectabilis which showed a negative correlation with previous year December temperatures and current year April, May-June temperatures in line with present study. According to Udas (2009), the negative relationship with winter temperature could be the respiratory loss of carbohydrate reserves during warm winters, thereby, impeding tree growth in the following growing season. Another possible explanation for the indirect relationship of winter temperature with tree growth could be early snowfall in the study area which would act as an insulator on the ground surface thus, protecting the rooting zone from freezing, thereby regulating winter cold stress over short time periods. If trees ceased their annual growth prematurely, then surplus photosynthetic carbohydrates could be stored for immediate growth at the start of the next growing season (Henderson and Grissino-Mayer, 2009).

High moisture during winter and early spring season was found beneficial or positive effect for the blue pine growth in the following growing season. The study area receives precipitation in the form of snow during winter and early spring season. The melting of which can provide continuous moisture supply for tree growth during the growth start in the spring season. A positive winter and spring season moisture signal in the tree growth is widely observed in the dry regions in the Himalayas (Thapa et al., 2015; Panthi et al., 2017; Gaire et al., 2017, 2019). Studies done in the Himalayas also show that tree growth in these regions is limited by moisture availability in the pre-monsoon season and can demonstrate a negative relationship with temperature and a positive one with precipitation (Boragaonkar et al., 1999; Sano et al., 2005; Thapa et al., 2015; Panthi et al., 2017). Similarly, Himalayan fir growing at higher elevations in Manang region is mainly limited by moisture stress rather than by low temperatures (Rai et al., 2019).

To this end, we found that the growth of the blue pine is fluctuating over time in accordance to climate change situation in the area. We found winter and spring season climate has major role for the pine growth in the subsequent growing season. Studies from the Himalayas have indicated higher rate of warming, and higher elevation getting warmer (Shrestha and Aryal, 2011). There is no consistent trend in the precipitation data from the Nepal Himalaya and its trend is increasing or decreasing in different stations (Shrestha and Aryal, 2011). Similar fluctuating situations exist in drought conditions (Panthi et al., 2017; Gaire et al., 2019). If the temperature will be increased continuously with decreasing precipitation, less snow falls or low snow accumulation in the winter and early spring season, it could adversely affect the blue pine forest growth in the study area in Himalayas. However, if there will be an increase in precipitation and snow accumulation concurrent with the warming, and if there will not be winter or spring season drought stress, the pine forest in the Himalayan region can take advantage for its growth in future, and growth of pine will be increased in future in response to climate change.

\section{Conclusion}

A century long tree-ring chronology of $P$. wallichiana was developed in the Kunjo area of the Mustang district of Nepal. The present study of $P$. wallichiana tree-ring and climatic relationships indicates that this species is suitable for dendroclimatic study, due to its clear and dateable treering sequences and synchronistic growth patterns. Winter and spring season moisture availability is found as a dominant climatic factor controlling the growth of this species. The dendroclimatic analysis from this investigation has potential to understand long-term dynamics of snowfall (winter precipitation) and climate change effects in the Himalayan region of Nepal. Long-term regional scale chronologies are required to understand current impacts of climate change on forest ecosystems. Continued development of long-term dendroclimatic chronologies in Himalayan conifers are needed to support climate change research and adaptation in the region. 
Acknowledgements. This study was funded by the Strategic Priority Research Program of Chinese Academy of Sciences, Pan-Third Pole Environment Study for a Green Silk Road (XDA 20040301). We thank the Beijing Forestry University, Nepal Academy of Science and Technology, and the Tribhuvan University, Institute of Forestry, Pokhara Campus for providing research facilities. The first author thanks the Chinese Government for the Ph.D. scholarship. We are also grateful to Rajesh Sigdel and all reviewers for their valuable comments and suggestions for improving the quality of this paper.

Conflict of Interests. The authors declare no conflict of interests.

\section{REFERENCES}

[1] Adhikari, D. (2018): Impact of Climate Change on Livelihood of Local People and Adaptation Strategies in Muktinath Valley, Mustang, Nepal. - B.Sc. Forestry Thesis submitted to Institute of Forestry, Tribhuvan University, Nepal.

[2] Aryal, P. C., Dhamala, M. K., Gaire, N. P., Bhatta, S., Suwal, M. K., Bhuju, D. R., Chhetri, P. K. (2020). Tree-ring climate response of two Larix species from the Central Nepal Himalaya. Tropical Ecology, 61(2), 215-225.

[3] Aryal, S., Bhuju, D. R., Kharal, D. K., Gaire, N. P., Dyola, N. (2018): Climatic upshot using growth pattern of Pinus roxburghii from western Nepal. - Pak. J. Bot 50(2): 579588.

[4] Asad, F., Zhu, H., Liang, E., Ali, M., Hamayun, M., Sigdel, S. R., Hussain, I. (2017): Climate signal in tree-ring width chronologies of Pinus wallichiana from the Karakoram Mountains in Northern Pakistan. - Pak. J. Bot 49(6): 2466-2473.

[5] Bhandari, S., Gaire, N. G., Shah, K. S., Speer, H. J., Bhuju, R. D., Thapa, U. K. (2019): A 307 years tree ring reconstruction indicates modern drought in western Nepal Himalayas. - Tree-Ring Research 75(2): 73-85.

[6] Bhattacharyya, A., LaMarche Jr., V. C., Telewski, F. W. (1988): Dendrochronological reconnaissance of the conifers of northwest India.

[7] Bhattacharyya, A., Chaudhary, V. (2003): Late-summer temperature reconstruction of the eastern Himalayan region based on tree-ring data of Abies densa. - Arctic, Antarctic, and Alpine Research 35(2): 196-202.

[8] Borgaonkar, H. P., Pant, G. B., Kumar, K. R. (1999): Tree-ring chronologies from western Himalaya and their dendroclimatic potential. - IAWA journal 20(3): 295-309. https://doi.org/10.1163/22941932-90000692.

[9] Bräuning, A. (2004): Tree-ring studies in the Dolpo-Himalya (western Nepal). - Tree Rings in Archaeology, Climatology and Ecology 2(44): 8-12.

[10] Christensen, M., Heilmann-Clausen, J. (2009): Forest biodiversity gradients and the human impact in Annapurna Conservation Area, Nepal. - Biodiversity and conservation 18(8): 2205-2221. https://doi.org/10.1007/s10531-009-9583-9.

[11] Cook, E. R., Holmes, R. L. (1986): User's manual for ARSTAN. - Laboratory of Tree-ring Research, University of Arizona, Tucson.

[12] Cook, E., Kairiukstis, L. (1990): Methods of dendrochronology. - Applications in the Environmental.

[13] Cook, E. R., Krusic, P. J., Jones, P. D. (2003): Dendroclimatic signals in long tree-ring chronologies from the Himalayas of Nepal. - International Journal of Climatology: A Journal of the Royal Meteorological Society 23(7): 707-732.

https://doi.org/10.1002/joc.911.

[14] Dawadi, B., Liang, E., Tian, L., Devkota, L. P., Yao, T. (2013): Pre-monsoon precipitation signal in tree rings of timberline Betula utilis in the central Himalayas. - Quaternary International 283: 72-77. https://doi.org/10.1016/j.quaint.2012.05.039. 
[15] Fan, Z. X., Bräuning, A., Cao, K. F., Zhu, S. D. (2009): Growth-climate responses of highelevation conifers in the central Hengduan Mountains, southwestern China. - Forest Ecology and Management 258(3): 306-313. https://doi.org/10.1016/j.foreco.2009.04.017.

[16] Fritts, H. C. (1976): Tree Rings and Climate. - Academic Press, 567p.

[17] Fritts, H. C., Blasing, T. J., Hayden, B. P., Kutzbach, J. E. (1971): Multivariate techniques for specifying tree-growth and climate relationships and for reconstructing anomalies in paleoclimate. - Journal of applied meteorology 10(5): 845-864.

[18] Gaire, N. P., Bhuju, D. R., Koirala, M. (2013): Dendrochronological studies in Nepal: Current status and future prospects. - FUUAST Journal of Biology 3(1 June): 1-9. http://fuuastjb.org/index.php/fuuastjb/article/view/254.

[19] Gaire, N. P., Koirala, M., Bhuju, D. R., Borgaonkar, H. P. (2014): Treeline dynamics with climate change at the central Nepal Himalaya. - Climate of the Past 10(4): 1277-1290. http://www.clim-past.net/10/1277/2014/cp-10-1277-2014.html.

[20] Gaire, N. P., Bhuju, D. R., Koirala, M., Shah, S. K., Carrer, M., Timilsena, R. (2017): Treering based spring precipitation reconstruction in western Nepal Himalaya since AD 1840. - Dendrochronologia 42: 21-30. https://doi.org/10.1016/j.dendro.2016.12.004.

[21] Gaire, N. P., Koirala, M., Bhuju, D. R., Carrer, M. (2017a): Site- and species-specific treeline responses to climatic variability in eastern Nepal Himalaya. - Dendrochronologia 41: 44-56. http://dx.doi.org/10.1016/j.dendro.2016.03.001.

[22] Gaire, N. P., Dhakal, Y. R., Shah, S. K., Fan, Z. X., Bräuning, A., Thapa, U. K., Bhuju, D. R. (2019): Drought (scPDSI) reconstruction of trans-Himalayan region of central Himalaya using Pinus wallichiana tree-rings. - Palaeogeography, Palaeoclimatology, Palaeoecology 514: 251-264. https://doi.org/10.1016/j.palaeo.2018.10.026.

[23] Gaire, N. P., Fan, Z. X., Bräuning, A., Panthi, S., Rana, P., Shrestha, A., Bhuju, D. R. (2020): Abies spectabilis shows stable growth relations to temperature, but changing response to moisture conditions along an elevation gradient in the central Himalaya. Dendrochronologia 60: 125675. DOI: 10.1016/j.dendro.2020.125675.

[24] Gautam, D., Karki, J., Gaire, N. P., Roth, B. E., Bhattarai, S., Thapa, S., ... Liu, Q. J. (2021). Intra-and interannual climate variability drives the radial growth of Pinus wallichiana in the Nepalese Himalayas. Plant Ecology \& Diversity, 13(5-6), 391-400.

[25] Grissino-Mayer, H. D. (2001): Evaluating cross dating accuracy: a manual and tutorial for the computer program COFECHA. - http://www.treeringsociety.org/.

[26] Grissino-Mayer, H. D., Butler, D. R. (1993): Effects of climate on growth of shortleaf pine (Pinus echinata Mill.) in northern Georgia: A dendroclimatic study. - Southeastern Geographer 33(1): 65-81. https://doi.org/10.1353/sgo.1993.0003.

[27] Harley, G. L., Grissino-Mayer, H. D., Horn, S. P. (2011): The dendrochronology of Pinus etiottii in the lower Florida Keys, Chronology development and climate response. - TreeRing Research 67(1): 39-50.

[28] Henderson, J. P., Grissino-Mayer, H. D. (2009): Climate-tree growth relationships of longleaf pine (Pinus palustris Mill.) in the Southeastern Coastal Plain, USA. Dendrochronologia 27(1): 31-43. https://doi.org/10.1016/j.dendro.2008.08.001.

[29] Holmes, R. L. (1983): Computer-assisted quality control in tree-ring dating and measurement. - http://hdl.handle.net/10150/261223.

[30] Jackson, J. K. (1994): Manual of afforestation in Nepal: Forest Research and Survey Center. - Kathmandu, Nepal.

[31] Kharal, D. K., Meilby, H., Rayamajhi, S., Bhuju, D., Thapa, U. K. (2014): Tree ring variability and climate response of Abies spectabilis along an elevation gradient in Mustang, Nepal. - Banko Janakari 24(1): 13473.

[32] Kharal, D. K., Thapa, U. K., George, S. S., Meilby, H., Rayamajhi, S., Bhuju, D. R. (2017): Tree-climate relations along an elevational transect in Manang Valley, central Nepal. Dendrochronologia 41: 57-64. https://doi.org/10.1016/j.dendro.2016.04.004. 
[33] Liang, E., Eckstein, D., Liu, H. (2008): Climate-growth relationships of relict Pinus tabulae form are at the northern limit of its natural distribution in northern China. - Journal of Vegetation Science 19(3): 393-406.

[34] Liang, E., Dawadi, B., Pederson, N., Eckstein, D. (2014): Is the growth of birch at the upper timberline in the Himalayas limited by moisture or by temperature. - Ecology 95(9): 24532465. https://doi.org/10.1890/13-1904.1.

[35] Mosteller, F., Tukey, J. W. (1977): Data analysis and regression: a second course in statistics. - Pearson.

[36] NTNC. (2008): Sustainable Development Plan of Mustang (2008-2013).

[37] Panthi, S., Bräuning, A., Zhou, Z. K., Fan, Z. X. (2017): Tree rings reveal recent intensified spring drought in the central Himalaya, Nepal. - Global and Planetary Change 157: 26-34. https://doi.org/10.1016/j.gloplacha.2017.08.012.

[38] Pfeifer, K., Kofler, W., Oberhuber, W. (2005): Climate related causes of distinct radial growth reductions in Pinus cembra during the last 200 yr. - Vegetation History and Archaeobotany 14(3): 211-220. DOI 10.1007/s00334-005-0001-2.

[39] Rai, S., Dawadi, B., Wang, Y., Lu, X., Ru, H., Sigdel, S. R. (2019): Growth response of Abies spectabilis to climate along an elevation gradient of the Manang valley in the central Himalayas. - Journal of Forestry Research 31: 2245-2254. http://doi.org/10.1007/s11676019-01011-x.

[40] Rinn, F. (2003): TSAP-Win. Time series analysis and presentation for dendrochronology and 409 related applications. - User reference. https://ci.nii.ac.jp/naid/10029733400/.

[41] Sano, M., Furuta, F., Kobayashi, O., Sweda, T. (2005): Temperature variations since the mid-18th century for western Nepal, as reconstructed from tree-ring width and density of Abies spectabilis. - Dendrochronologia 23(2): 83-92. https://doi.org/10.1016/j.dendro.2005.08.003.

[42] Schmidt, B., Wazny, T., Malla, K., Höfs, E., Khalessi, M. (1999): Chronologies for historical dating in high Asia/Nepal. Tree-Ring Analysis. - Biological, Methodological and Environmental Aspects, pp.205-211.

[43] Schweingruber, F. H. (1992): Annual growth rings and growth zones in woody plants in southern Australia. - IAWA Journal 13(4): 359-379. https://doi.org/10.1163/2294193290001290.

[44] Shah, S. K., Bhattacharyya, A., Chaudhary, V. (2009): Climatic influence on radial growth of Pinus wallichiana in Ziro Valley, Northeast Himalaya. - Current Science 96(5): 697702. https://www.jstor.org/doi/24104565.

[45] Shah, S. K., Pandey, U., Mehrotra, N., Wiles, G. C., Chandra, R. (2019): A winter temperature reconstruction for the Lidder Valley, Kashmir, Northwest Himalaya based on tree-rings of Pinus wallichiana. - Climate Dynamics 53(7-8): 4059-4075. https://doi.org/10.1007/s00382-019-04773-6.

[46] Shrestha, A. B., Aryal, R. (2011): Climate change in Nepal and its impact on Himalayan glaciers. - Regional Environmental Change 11(1): 65-77. https://doi.org/10.1007/s10113010-0174-9.

[47] Sigdel, S. R., Dawadi, B., Camarero, J. J., Liang, E., Leavitt, S. W. (2018): MoistureLimited Tree Growth for a Subtropical Himalayan Conifer Forest in Western Nepal. Forests 9(6): 1-13. https://doi.org/10.3390/f9060340.

[48] Singh, J., Yadav, R. R. (2000): Tree-ring indications of recent glacier fluctuations in Gangotri, western Himalaya, India. - Current Science 79(11): 1598-1602.

[49] Sohar, K., Altman, J., Lehečková, E., Doležal, J. (2017): Growth-climate relationships of Himalayan conifers along elevational and latitudinal gradients. - International Journal of Climatology 37(5): 2593-2605. https://doi.org/10.1002/joc.4867.

[50] Speer, J. H. (2010): Fundamentals of Tree-Ring Research. - The University of Arizona Press. https://doi.org/10.1002/gea.20357.

[51] Stocker, T. F., Qin, D., Plattner, G. K., Tignor, M., Allen, S. K., Boschung, J., Midgley, P. M. (2013): Climate change 2013: The physical science basis. - Contribution of working 
group I to the fifth assessment report of the intergovernmental panel on climate change 1535. http://www.climatechange2013.org/.

[52] Thapa, U. K., Shah, S. K., Gaire, N. P., Bhuju, D. R. (2015): Spring temperatures in the far-western Nepal Himalaya since AD 1640 reconstructed from Picea smithiana tree-ring widths. - Climate dynamics 45(7-8): 2069-2081. https://doi.org/10.1007/s00382-0142457-1.

[53] Thapa, U. K., St. George, S., Kharal, D. K., Gaire, N. P. (2017): Tree growth across the Nepal Himalaya during the last four centuries. - Progress in Physical Geography 41(4): 478-495. https://doi.org/10.1177\%2F0309133317714247.

[54] Udas, E. (2009): The Influence of Climate Variability on Growth Performance of Abies spectabilis at Tree Line of West-Central Nepal. - MSc. thesis, Ernst Moritz Arndt University of Greifswald, Germany.

[55] Wigley, T. M., Briffa, K. R., Jones, P. D. (1984): On the average value of correlated time series, with applications in dendroclimatology and hydrometeorology. - Journal of climate and Applied Meteorology 23(2): 201-213. https://doi.org/10.1175/1520-0450 (1984)023\%3C0201.

[56] Yadav, R. R., Bhattacharyya, A. (1996): Biological Inferences from the Growth Climate Relationship. - Proc. Indian natn. Sci. Acad 62(3): 233-238. https://www.insa.nic.in/writereaddata/PINSA/Vol62B_1996_3.

[57] Yadav, R. R., Amalava, B. (1997): Climate and growth relationship in blue Pine (Pinus wallichiana) from the western Himalaya, India. - The Korean Journal of Ecology 20(2): 95-102. http://www.koreascience.or.kr/article/JAKO199711919962508.

[58] Ziaco, E., Biondi, F., Rossi, S., Deslauriers, A. (2014): Intra-annual wood anatomical features of high-elevation conifers in the Great Basin, USA. - Dendrochronologia 32(4): 303-312. http://dx.doi.org/10.1016/j.dendro.2014.07.006. 